\title{
AIMS AND WORK OF THE HAMBURG SMOKE ABATEMENT SOCIETY.
}

\author{
By JOHN 13. C. IEERSIIAT, F.I.C.
}

\begin{abstract}
$N^{\mathrm{k}}$ EARI I everyone agrees that smoke means loss of money both to the indivirlual producing it and to the individual whose house, lands, possessions, or person are limmager amıl blackened by its later descent in the form of smuts, sulphurous rapour, and black fog. There is, consequently, no neer to discuss the health or economic side of the smoke problem. What we have gathereel here to discuss is the more practical and useful question, to what extent is smoke-abatement possible nou, both as resards the manufacturing and domestic use of coal ! To-day we leal with the suljject of Factory and Trade Smoke. I am not exaggerating when I state that four-fifths of this is proluced by the unscientific comelitions under which coal is uned in the furnaces of boiler's and other leating appliances.

The recently publishes Report of the Royal Commission upon aur coilsupplies, contained the startling statement that of the 150 million tons of coil used annually in this country, an economy of from 40 to tio nillion tons, or arer 33 jer cent., was possible by greater attention to the scientific principles of fuel-combustion. The Commissioners also stater that about 5: millions of tons of coal were used annually for steamraising purposes, anl that the arerage consumption per i.-p. hr. was about i lbs. When one comprares with this figure the actually recorded consumption of $1.3 \mathrm{lbs}$." per h.-p. lir. for marine engines, one sees what an enormous waste of fuel is now occurring, and what scope there is for the organized attempt now being male to obtain a more scientific use of fuel in our manufacturing industries. This paper will cleal with a practical branch of the subject:-namely, the methods of voluntary supervision and control adopted in Hamburg for obtaining greater efficiency and less smoke from the factory-boiler installations in that city.

It is somewhat striking that this example of what can he achievel hy voluntary effort, should come to us from Germany, the land of bureaucracy
\end{abstract}

* SS. Saxunia trials in 1002 . 


\section{$16+$ Aims and Worte of thr IHambury Smoke Abrtement Society.}

and State control. The Hambury lerein fïr Feuerngs-betrisb und Rauchhekimlfing is, however, an entirely voluntary organization of steam-users, and its members are only bound together by the common clesire to obtain greater efficiency and less smoke from their steam-raising plant. The Socicty has now been in existence three and a quarter years, and the following account of its organization, aims and work is drawn from an explanatory pamphlet and from the two annual reports which have been issued since its inauguration in October, 1902.

The work of the Society is controlled ly a committee of six to nine members, elected annually. The technical and scientific work is undertaken by the staff of experts retained by the society for this special work. At the date of the last report this sraff consisted of a chief engineer, two assistant engineers, two instructors for firemen, and one clerk, while for special steam-laising and other trials, three additional assistants had also been employed. The chief engineer attends the committee meetings and takes part in the discussions relating to the work of the Society. The funds of the society are drawn from three sources:-From the :mmual subscriptions of its members: from payment for special work and reports for its members; from parments for outside work.

The Society is thus entirely self-supporting, and its success is dependent upon the value of the return it makes to its members for their contributions and fees. It is therefore gratifying to note that the membership shows stealy growth. Starting with a few members in October, 1902 , the register contained 60 tirms and $24 ! 4$ hoilers at the end of September, 1903, and fifteen montlis later these hat increased to 11;) firms and 3.51 boilers. The report for the rear 194.5 is not yet pulblished, but I am informed by the chief engineer that the membership is now 1.j0, with 420 boilers under their control.

The objects of the Society, as set forth in the rules, are the attainment of the highest possible efficiency from the heating and boiler plants of its members, with the least possible emission of smoke. To this end, regular examination of these plants and of the methods of working them is undertaken by the expert staff of the Society, and suggrestions are made for improvements when such are required. The education and control of the firemen in the proper performance of their duties, are also undertaken by the fireman-instructors on the staff of the Socicty. Comparative tests of fuel, and tests of smoke-prevention and other appliances of a similar character, are also carried out by the expert staff, and the results are circulated amongst the members of the Society.

Members of the Society can demand that their boiler or heating plant 
shall be regularly inspected, and that its working shall be tested and reported on, at least three times a year. They have also the right to consult the chief engincer of the Society regarding improvements and alterations in the slesign and working of their plant.

They on their side are bound to allow the chief engineer and other members of his staff free access to their heating and boiler plant at all times, and are bound to make the necessary provisions for conducting the tests. They are also required to carry out the suggestions made for improving the efficiency of the plant, especially as regards the aluatement of smole, and to submit to the chief enginecr all plans for extension of the plint, or for change in the methods of work.

Each boiler or heating plant, when brought under the control of the exyert staff of the rocietry, is tested at the earliest possible date, and a written report upon the results of the examination is suhmitted to the owner. Should the firing have proved inetticient, one of the firemen instructors is sent to the works to give practical instruction to the firemen employed there, and tests of the plant are made at intervals until this fault is remedied. Defects in design are similarly dealt with.

The annual subscription to the Society for members without any boiler or heating plant, is 20 marks ( $£ 1$ ). Members having boilers or furnaces which they desire to place under the control of the experts of the Society, pay a further 20 markis annually for each boiler or furnace.

The extra charges for tests and reports are hased upon the time spent upon them and the number of experts employed. Engineer's are charged for at the rate of 20 marks per clay, and firemen-instructors at 5 marks per day. Special reports upon patented appliances are charger for at the customary rates; members receive a special discount of 30 per cent. (m these, as compared with outsiclers.

Turning to the work of the Society as set forth in the two voluminous reports which have been issued, one finds that the greatest stress is laid upon the improved efficiency obtained by the instruction of firemen in the proper performance of their duties. This corroborates the view held bymany authorities in this country, that improper methods of firing are largely responsible for the smoke-problem. ${ }^{\top}{ }^{2}$, to Octuber 1st, 1:10:3, $1 \% 0$ firemen had been specially trained by the officer's of the Soriety, and by Decemler, 1!104, this total had been increased to 300 . As evidence of the loss in efficiency of steam-raising plants, due to this cme cause alone, the following figures are given in the earlier report :-

Thermal efficiency, with the regular liut untrained stokers $66 b^{\circ} l i$ per cent. Thermal efficiency of same plant, with trained stokers $\ldots$ i $7 \cdot 7$ " 
In the plant where these tests were make, this loss of $t \cdot 1$ perp cent. in the fuel-efticiency representerl a loss of $: 4 \mathrm{~s}$. per clay, or \pm 10 per week of 144 hours. In another test the loss clue to the use of untrained stokers rose to Iti.I per cent., the thermal efficiency being increased from $66 \cdot 4$ per cent. to $82 \cdot 9$ per cent., by mere change of the firemen working the plant.

In this connection the engineer of the Hamburg Society wisely emphatsises the fact that the attempt at smoke-abatement by untrained stokers, withont scientific supervision, generally ends in failure; for their plan is simply to allow air in enomous excess to How through the furnaces, which means great losses ilue to the heat passing away up the rhimmey, and high fuel-costs per poumd of water evaporated. The highest tests given in these reports show heat losies from this cause amounting to 27.4 per cent., or orer one-fourth of the heat-value of the fuel hurnt.

The other branch of the Society's work (namely, alteration in the design and methods of working of the plants umder their (charge) is alvo dealt with in these two reports, and the following shows the improvenents obtained by the systematic and scientific control inmgurated hy the Society, in place of the haphazard and rule-of-thumb methenls whirh had preceded this, in the boiler-phants dealt with :--.-

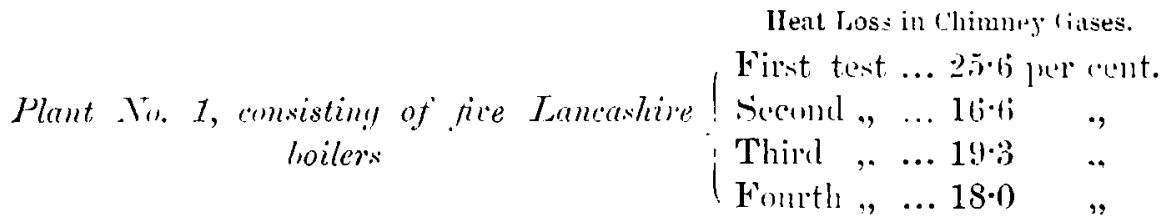

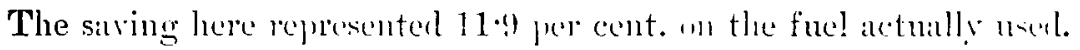

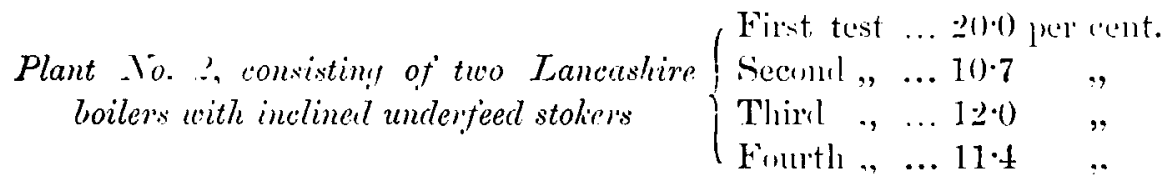

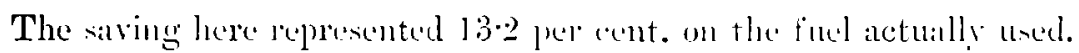

Plant .'o. '; consisting of tuo water-tube ( First test ... 1!) is per cent. boilers i Fecond , ... 12.2 ,

The saving here representerl !) 7 gere cent. on the fuel actually used.

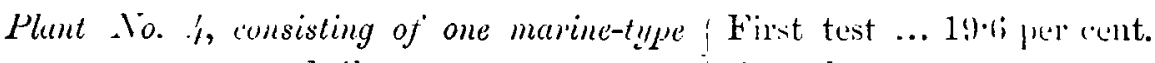
boiler. (Ferond , $\quad \ldots \quad 7 \div 1$,

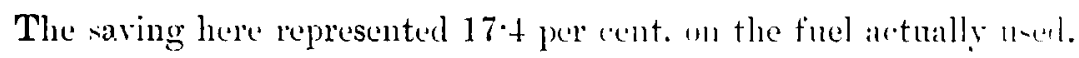


In these test-results, the first represents the original trial under the ordinary conditions of working; the secomd represents the results ubtained when the plant hat been altered on scientific lines and wats worked hy the expert staff of the Suciety; while 3 and + represent the results olitained at some later date, when the plant was again under the control of the ordinary stukers and boiler engineer attached to the works. The efficiency in this case had fallen back slightly, as might be expecterl, but was still much better than in the original test.

Limit of space will not allow more ketailed figures of test.s to be given from the two reports of the Hambur. Sucicty, and those interested are referred to the original pamphlets. The following summary from the Report for the year 1904 will show, lewerer, the activity of the new organization :-

Duringr the fourteen month enling December 31st, 19104, 32-2 installations were submitted to the first thorough cxamination and test, and $i 1$ firemen reroived instruction in their duties at these plants for a period of 15) days. it installations were risited for the second, third and fourth time, and in annection with these risits 190 tests were made, as a check upun their continued noon working. The munher of reports issued trom the central offiee in connection with these and other tests wass 226 .

As a proof of the position which the Society has attained in Hamburg and Germany, it may be stated that a sum of $\mathfrak{E} 300$ was granted to it in 1903, in orler to carry out some special steam-raising trials, and a central molel boiler installition was ererted in IIamburg for this work. One hundred and thirty complete steam-raising trials have been malle at this model boiler plant during $]$ ! 144 , and the results obtained are to be circulated amongst the members of the rocinty in a special report. A summary of the jesults of tinese trials is contaned in the report for the year ending December 31st, 1904.

The practical lesson which we in this country may learn from the above account of the work of the Hamburg society, is, I think, that the smoke-problem is to he solved, like many another problem, by application of that old English method of self help, which is now sadly out of fashion. Manufacturers, and fuel-users generally, in this country, must be tanght that the emission of hack smoke is largely proventable, and that the smokeless combustion of fuel promotes economy, when carried out under proper supervision. It is for this reason that the writer has given instances from the annual reports of the If:mburg society to prove the salving in fuel-consumption which results from the working of steam-boiler plants on scientific lines, with properly trained stukirs. 
168 Aims and Worli of the IIumburg Smoke Abutement Society.

What is wanted in this country is some society or organization which will provide fuel-users with the technical arlvice and oversight required for obtaining the smokeless combustion of fuel in their own works. The Hamburg Society, in the author's opinion, is such an organization, since it is showing manufacturers how to combine together to attack the evil at its source, namely, the boilor and heating installations in their own works. It would be well if similar societies were started in every large centre of manufacturing industry in this country. The writer, as foreign corresponding member of the Hamburg society, will be pleased to give all the information in his power, relating to the organization and work of the Society which he represent: here to-dily; and of which he has given a brief account in this paper. 